\title{
A Taxonomic Research on the First Record of the Genus Miyadiella Kubo, 1949 by Kunju from Indian Water
}

Angsuman Chanda*

PG Department of Zoology, Raja N. L. Khan Women's College, Midnapur, Paschim Medinipur, West Bengal, India

\begin{abstract}
The genus Miyadiella was described by Kubo represents two species namely Miyadiella podophthalmus Stimpson and Miyadiella ornate. The validity of the genus was questioned by Starobogatov, Holthuis and Burkenroad. Type species of the genus Miyadiella pedunculata was synonymiesed under Penaeus podopthalmus by Starobogatov and the genus was synonymised under Atypopenaeus created by Alcock. But it was Hayashi who strongly stated that long eyestalk is the typical character for the genus Miyadiella. Pérez-Farfante and Kensley also supports Hayashi's view and tentatively keeps separate Miyadiella from Atypopenaeus by adding two additional typical characters for the genus like presence of spinules on first rostral teeth as well as along the postrostral carina and relatively short fifth periopod. During the present study author got the opportunity to study the materials preserved in Central Marine Fishery Research Institute (CMFRI), Cochin, Tamil Nadu, India [Reg. No. AR. 267, from Bombay, collected by Kunju and labeled as Atypopenaeus stenodactylus, and arrived into conclusion that the specimen will be Miyadiella podopthalmus.
\end{abstract}

Keywords: Taxonomic remarks; Materials; Marine; Fishery; Prawns

\section{Introduction}

Among a variety of edible decapod crustaceans, prawns contribute largely to the fishery wealth of many nations. Exploitation of prawn resource from the seas around each country is playing increasingly significant role in furthering their national economy [1-4]. In recent years, in spite of some ecological hazards, the demand for prawns and prawn products has increased so much that every country is making efforts to utilize hitherto unknown but usable stocks and expansion of prawn fisheries and industries near coast line is rightly being given the maximum encouragement in the development programme of each nation. In India, with the introduction of mechanization and due to the development of efficient export industries, prawn fishery has substantially improved during last three decades. The foreign exchange earnings by export of prawns and prawn products from the country have grown up considerably. In short, as in every prawn fisheries together with all the segments of the industry concerned with prawn products export are playing increasingly prominent role in the economy of the country. Given this economic significance and the fact that penaeid prawns occur in a wide variety of shallow-water marine, estuarine and back water habitats, knowledge on the ecology, feeding, reproduction, lifecycle, fecundity, prey predator relationship, behavior, population dynamics and fisheries potentials have vastly increased over the last three decades [5-9]. The knowledge of the systematics of prawns is an essential prerequisite for their wise management and exploitation. Earliest contribution on the penaeid prawn from Indian water was by Fabricius [10]. Some important contributions on the prawns of this region during nineteenth century were by Milne Edwards [11], Miers [12], Bate [13], Wood-Mason[14], Wood-Mason and Alcock [15] and Alcock and Anderson [16,17]. Alcock [7,18,19] and George [20] was the taxonomist of 20th century who tried to make a comprehensive study on the penaeid taxonomy. Beside these there are so many taxonomic works on the group like by Fischer and Bianchi [21], Paulinose [22], Achuthankutty and Parulekar [23], Reddy [24], Pathan and Jalihal [25], Chanda and Bhattacharya [26-30], Chanda and Roy [31,32], Chanda [33-36]. In spite of these work, there are some lacuna on the penaeid systematics and distribution of Indian region.

So, present work is an attempt to fill up one of such lacuna found by the author on genus Miyadiella [1] during the study. Present study reveals that Indian water represents only one species of the genus Miyadiella [1] i.e., Miyadiella podophthalmus [2] recorded by Kunju [37] from Maharastra as Atypopenaeus stenodactylus [2]. Apparently, Atypopenaeus stenodactylus and Miyadiella podophthalmus shows morphologically similar due to delicate body, integument with setae; rostrum short, reaching beyond middle of first antennular segment, armed only with dorsal teeth; epigastric tooth separated from first rostral tooth; carapace with rounded orbital angle, antennal spine short, post-orbital sulcus rounded, hepatic spine short, pterygostomian spine absent. But closure examination shows that structure of petasma, thelycum, long eye stalk; spinules on first rostral tooth and post rostral carina are the distinguishing characters of Miyadiella podophthalmus.

\section{Materials and Methods}

The present study is mainly based on the observation of specimens preserved in the general collection of CMFRI, Cochin, Tamil Nadu (Reg. No. AR. 267, from Bombay, collected by Kunju). The materials preserved in rectified spirit (90\%) were studied under a stereoscopic binocular microscope. The detailed synonymies have been furnished to the genus and species and also their diagnosis, distribution, taxonomic remarks have been furnished. In addition an attempt has been made to include a comprehensive coverage of the references in the reference section. For all citations of taxon author's name and year of publication has been given. A brief history, diagnosis and distribution of the species are dealt separately in results and discussion section.

*Corresponding author: Angsuman Chanda, Asst. Professor, PG Dept. of Zoology, Raja N. L. Khan Women's College, Midnapur, Paschim Medinipur, West Bengal, India, Tel: 9932675019; E-mail: angsumanchanda@yahoo.in

Received June 08, 2015; Accepted June 20, 2015; Published June 25, 2015

Citation: Chanda A (2015) A Taxonomic Research on the First Record of the Genus Miyadiella Kubo, 1949 by Kunju from Indian Water. J Aquac Res Development 6: 366. doi:10.4172/2155-9546.1000366

Copyright: ( 2015 Chanda A. This is an open-access article distributed under the terms of the Creative Commons Attribution License, which permits unrestricted use, distribution, and reproduction in any medium, provided the original author and source are credited. 


\section{Results and Discussions}

\section{Genus Miyadiella Kubo, 1949}

The genus Miyadiella was created by Kubo [1] with M. pedunculata as type from Osaka-Wam, Japan. The genus was first recorded from India by Kunju [37] from Maharastra, West Coast of India as Atypopenaeus. A brief history with special reference to Indian contributions is listed below.

Stimpson W (1860) Prodromus descriptionis animalium evertebratorum, quae in expeditione ad oceanum Pacificum septentrionalem, a Republica Federata missa, Cadwaldaro Rinngold et Johanne Rodgers ducibus, observavit et descripsit. VIII. Proc Acad Nat Sci Philad 12: 43 [2].

Kubo I (1949) Studies on penaeids of japanese and its adjacent waters. Tokyo College of Fisheries 36: 1-467.Dall et al. (1990) Adv Mar Biol 27: 1-489 [1].

Kunju MM (1967) Observations on the prawn fishery of Maharashtra coast. Symp Ser Mar Biol Assoc India (2): 1382-1397 [37]

Kurian, Sebastian (1993) Prawns and Prawn Fisheries of India. Hindustan Publishing Corporation, Delhi, pp. 1-280 [38].

Type Species: Miyadiella pedunculata: Kubo I (1949) Studies on penaeids of japanese and its adjacent waters. Tokyo College of Fisheries 36: 1-467 [1].

Penaeus podophthalmus: Stimpson W (1860) Prodromus descriptionis animalium evertebratorum, quae in expeditione ad oceanum Pacificum septentrionalem, a Republica Federata missa, Cadwaldaro Rinngold et Johanne Rodgers ducibus, observavit et descripsit. VIII. Proc Acad Nat Sci Philad 12: 43 [2].

Type Locality: Osaka-Wam, Japan.

\section{Diagnosis of the genus}

Integument with setae; rostrum short, not reaching distal margin of first antennular segment, with dorsal teeth only; epigastric tooth markedly separated from first rostral tooth; spinules on first rostral teeth; orbital spine absent, antennal spine prominent; pterygostomian angle blunt; hepatic spine sharply pointed; postrostral carina extending to about midlength or three-fourths of carapace, bearing rows of minute spinules; post-ocular sulcus well marked, sulcus variable in size; hepatic sulcus and carina distinct anteriorly, extending anteroventrally, indistinct posteriorly; branchiocardiac carina long, indistinct; longitudinal and transverse suture absent; sixth abdominal somite without cicatrices; telson elongate without spine, with few spinules and several, elongated, plumose marginal setae; eye extremely elongate, reaching upto midlength of third antennular segments; parapenaeid spine absent; first and second antennular segments elongated, flagella subequal, dorsal one slightly longer than ventral, shorter than carapace; basial spine present on second and third segment may be absent in first; ischial spine present on first, second and third pereopod; petasma semi-open, symmetrical, median and lateral lobes simple, not folded, median lobe bearing moderately broad proximal projection, lateral lobe long; thelycum open, with broad anteromedian spine on sternite XIV, preceded by rounded scales with elongate flap like lateral plates; median protuberance of sternite XIII either short, sometimes extending upto sternite XIV.6.

\section{Remarks}

Miyadiella and Atypopenaeus are two closely related genera which are difficult to distinguish. Pérez-Farfante and Kensley [9] supported Hayashi's [8] observation of long eye stalk, as the typical character of the genus Miyadiella and added some additional characters likespinules on first rostral tooth and post rostral carina, which is also typical to Miyadiella, and furthermore relatively s horter fifth pereopod are sufficient to separate the two genus. In India the genus Miyadiella is very rare and still date only one species Miyadiella podopthalmus [2] is known from India.

\section{Miyadiella podophthalmus [2]}

M. podophthalmus was originally described by Stimpsons [2] from Hong Kong as Penaeus podophthalmus. Hayashi [8] transfer the species to genus Miyadiella. The species was first recorded from India by Kunju [37] from Maharastra, West coast of India as Atypopenaeus stenodactylus. A brief history of the species with special reference to Indian contributions is given below:

Penaeus podophthalmus: Stimpson W (1860) Prodromus descriptionis animalium evertebratorum, quae in expeditione ad oceanum Pacificum septentrionalem, a Republica Federata missa, Cadwaldaro Rinngold et Johanne Rodgers ducibus, observavit et descripsit. VIII. Proc Acad Nat Sci Philad 12: 43 [2].

Atypopenaeus stenodactylus: Kunju MM (1967) Observations on the prawn fisheries of Maharashtra coast. Proc Symp Crustacea 4: 1382-1397 [37].

Miyadiella podophthalmus: Hayashi KI (1992) Dendrobranchiata crustaceans from Japanese waters. Tokyo Seibutsu Kenkyusha 1: 1- 300 [8].

Type Species: Penaeus podophthalmus: Stimpson W (1860) Prodromus descriptionis animalium evertebratorum, quae in expeditione ad oceanum Pacificum septentrionalem, a Republica Federata missa, Cadwaldaro Rinngold et Johanne Rodgers ducibus, observavit et descripsit. VIII. Proc Acad Nat Sci Philad 12: 43 [2].

\section{Type Locality: Hong Kong.}

\section{Material Examined}

No specimens were collected during present study but author examined one male (62 mm.), CMFRI Reg. No. AR. 267, from Bombay, collected by Kunju [37].

\section{Diagnosis of the species}

Integument with setae; rostrum short, reaching beyond middle of first antennular segment, armed dorsally with $7+1$ teeth; epigastric tooth separated from first rostral tooth; spinules on first rostral teeth; carapace with rounded orbital angle, antennal spine short, post-orbital sulcus rounded, hepatic spine short, pterygostomian spine absent; post rostral carina extending upto midlength of carapace, bearing rows of minute spinules, first rostral tooth also bearing minute spinules; cervical sulcus short, cervical carina marked; hepatic sulcus and carina marked anteriorly, anteriorly curved downwards, branchiocardiac carina long, not prominent; telson armed with three pairs of lateral spines; eye extremely elongate, reaching upto midlength of second antennular segment; antennular flagella subequal, dorsal one longer; basial spine present on second and third pereopod, ischial spine on first, second and third pereopod; fifth pereopod reaching to the end of basal third of the scaphocerite; petasma semi-open, symmetrical, with minute cincinnuli along dorsomedian margin; median and lateral lobes simple, not folded, median lobe bearing moderately broad proximal projection, lateral lobes, long rather flexible costa; thelycum open, 
Citation: Chanda A (2015) A Taxonomic Research on the First Record of the Genus Miyadiella Kubo, 1949 by Kunju from Indian Water. J Aquac Res Development 6: 366. doi:10.4172/2155-9546.1000366

Page 3 of 3

bearing basally broad anteromedian spine on sternite XIV, preceded by elongate flap like lateral plates.

\section{Remarks}

Material examined agree completely with the description of M. podophthalmus (Stimpson, 1860) and hence, A. stenoductylus as recognised by Kunju [37] has been regarded as Miyadiella podophthalmus in the present study and Kunju was the scientist who collected the specimen of genus Miyadiella, first time from Indian water.

\section{Distribution}

India: Maharashtra, West coast of India.

Elsewhere: south China Sea; Japan; Hong Kong.

\section{Acknowledgement}

Author is thankful to the Director, Zoological Survey of India for awarding a research fellowship during which the study has been done. Author is also thankful to Professor Tanmoy Bhattacharya, Ex-Emeritus Professor of Zoology, Dept. of Zoology, Vidyasagar University, Midnapur and West Bengal for his valuable advice and guidance during the preparation of manuscript. Author is also grateful to DBT, Govt. of India for financial support.

\section{References}

1. Kubo I (1949) Studies on penaeids of japanese and its adjacent waters. Tokyo College of Fisheries 36: 1-467.

2. Stimpson W (1858) Prodromus descriptionis animalium evertebratorum quae in expeditione ad oceanum pacificum sententrionalem a republica federata missa, cadwaladaro ringgold et Johanne Rodgers Ducibus observavit et descripsit. Proceedings of the Academy of Natural Sciences of Philadelphia 9: 216-221.

3. Holthuis LB (1955b) Crustaces Decapodes Macrures. Result Sci Exped Oceanogr Belge Atl Sud 3: 1-88.

4. Starobogatov YI (1972). Peneid (sem Peneidae Crustacea Decapoda) Tonkinskogo Zaliva Penaeidae (Crustacea Decapoda) of Tonking Gulf. Explor Fauna Seas 10: 359-415

5. Holthuis LB (1980) FAO species catalogue vol1 shrimps and prawns of the world. FAO Fisheries Synopsis 1: 1-271.

6. Burkenroad MD (1983) Natural classification of Dendobranchiata, with a key to recent genera. Crustacean Phylogeny 1: 279-290.

7. Alcock A (1905) A revision of the "Genus" Peneus with diagnoses of some new species and varieties. Annals and Magazine of Natural History 16: 508-532.

8. Hayashi KI (1992) Dendrobranchiata crustaceans from Japanese waters. Tokyo Seibutsu Kenkyusha 1: 1- 300.

9. Farfante IP, Kensley B (1997) Penaeoid and sergestoid shrimps and prawns of the world. Keys and diagnoses for the families and genera. Memoires du Museum National d'Histoire Naturel 175: 1-233.

10. Fabricius JC (1798) Supplementum Entomologiae systematicae: (Hafniae apud Proft et Storch)

11. Milne Edwards, H (1834). Histoire naturelle des crustacés comprenant l'anatomie la physiologie et la classification de ces animaux: (Librairie encyclopédique de Roret), Paris.

12. Miers EJ (1878). Notes on the penaeidae in the collection of the British Museum with descriptions of some new species. Proceedings of the Zoological Society of London 1878: 289- 310.

13. Bate CS (1888) Report on the crustacea macrura collected by H.M.S. challenger during the years 1873-1876. Report Scientific Results Voyage Challenger 24: $1-942$.

14. Wood-Mason J (1891) Natural history notes from H.M. Marine Surveying Steamer 'Investigator'. Ann Mag nat Hist 13: 321-334.

15. Wood-Mason J, Alcock A (1891) Natural history notes from H.M. Indian marine survey steamer 'Investigator' commander RF Hoskyn RN commanding No 21 note on the results of the last season's deep-sea dredging. Ann Mag nat Hist 7: 1-19.
16. Alcock A, Anderson AR (1894) Natural history notes from H.M. Indian marine survey steamer 'Investigator', commander CF Oldham RN commanding series 11 No 14 an account of the recent collection of deep-sea crustacea from the Bay of Bengal and Laccadive Sea. J Asi Soc Bengal 63: 141-185.

17. Alcock A, Anderson AR (1899) Natural history notes from H.M. Royal Indian marine survey ship 'Investigator' commander TH Heming RN commanding series III No 2 an account of the deep-sea crustacea dredged during the surveying-season of 1897-98. Ann Mag nat Hist 7: 278-292.

18. Alcock A (1901) A descriptive catalogue of the Indian deep-sea Crustacea Decapoda Macrura and Anomala, in the Indian Museum.

19. Alcock A (1907) Catalogue of the Indian Decapod Crustacea in the collection of the Indian Museum part III Macrura. Fasciculus I the prawns of the peneus group. Indian Museum 19: 127-127.

20. George MJ (1979) Taxonomy of Indian prawns (Curstacea, Decapoda Penaeidae) "in contribution to Marine Science" dedicated to Dr. C.V. Kurian: 21-59.

21. Fischer W, Bianchi G (1983) FAO Identification Sheets for Fishing Purposes. Western Indian Ocean Fishing 5.

22. Paulinose VT (1986) Larval and postlarval stages of Atypopenaeus Alcock (Decapoda, Penaeidae, Penaeinae) from Indian Ocean Mahasagar. Bull Nat Inst Oceanogr 19: 257-264.

23. Achuthankutty CT, Parulekar AH (1986) Growth of penaeid prawns in Goa waters. Indian J mar Sci 15: 117-120.

24. Reddy KN (1995) Estuarine Ecosystem Series, Part 2: Hugli Matla Estuary (Zool Surv) India.

25. Pathan DI, Jalihal DR (1997) Proposed taxonomic revision of some important penaeid prawn genera (Crustacea, Decapoda) of Konkan coast (west coast of India). J Bombay Nat Hist Soc 94: 496-514.

26. Chanda A, Bhattacharya T (2002) Melicertus similis a new species of prawn Decapoda Penaeidae from India. J B Nat Hist Society 99: 495-498.

27. Chanda A, Bhattacharya T (2003) Fenneropenaeus Konkani a new species of prawn (Decapoda: Penaeidae) from Indian Coast. Sci and Cult 69: 229-230.

28. Chanda A, Bhattacharya T (2004) A new species of the genus Parapenaeopsis Alcock 1901 (Penaeoidea:Penaeidae) from Orissa. India Proc Zool Soc Calcutta 57: 23-27.

29. Chanda A, Bhattacharya T (2009) Zoogeographic Distribution of Indian penaeidae proscidings of the International seminar on modern trends in biological sciences. (Raja N.L.Khan Women College Midnapore WB), India.

30. Chanda A, Bhattacharya T (2014 A systematic study on Indian records of Atypopenaeus Alcock 1905 with special reference to extended distribution of Atypopenaeus stenodactylus (Stimpson, 1860). Int J Sc Tech 2: 11-14.

31. Chanda A, Roy T (2004) Prawns of Gujarat Coast. Zool Surv India State Fauna Series 8 Fauna of Gujarat 211-218.

32. Chanda A, Roy T (2005) CRUSTACEA DECAPODA PANAEOIDEA. Zool Surv India State Fauna Series 5 Fauna of Andhra Pradesh 5: 537-550.

33. Chanda A (2014a) First Record of Two Australian Species One under Metapenaeopsis and Another under Metapenaeus from Indian Water their diagnosis and distribution. J Ento Zoo Studies 2: 18-20.

34. Chanda A (2014b) A systematic study on genus Metapenaeous Wood-Mason 1891 with special reference to extended distribution of four species from Indian water. International Journal of Fisheries and Aquatic Studies 2: 05-16.

35. Chanda A (2014c) Revision to the diagnostic characters of Trachypenaeopsis minicoyensis Thomas1972. Int J Sc Tech Res 3: 369-370.

36. Chanda A (20115) A study on the Indian records of the species under genus Megokris Perez Farfante \& Kensley 1997. International Journal of Current Research 7: 14920-14923.

37. Kunju MM (1967) Observations on the prawn fisheries of Maharashtra coast Proc Symp Crustacea 4: 1382-1397.

38. Kurian, Sebastian (1993) Prawns and Prawn Fisheries of India. Hindustan Publishing Corporation Delhi 1-280. 